\title{
Community perspectives of former terrorist combatants, militants and reintegration programmes in Nigeria: A systematic review
}

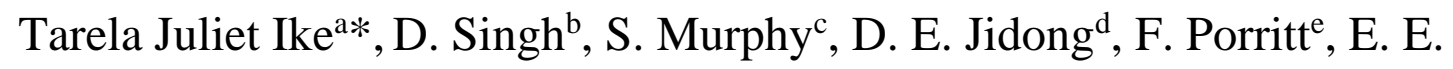
Ayobi $^{\mathrm{f}}$

a,b,ce, School of Social Science Humanities and Law, Teesside University, United Kingdom ${ }^{d}$ School of Social Sciences, Nottingham Trent University, Nottingham, United Kingdom

T.ike@tees.ac.uk*corresponding author

${ }^{a}$ Lecturer in Criminology and Policing with research interests and specialism on terrorism, counterterrorism, and peacebuilding in post conflict context. benior lecturer in Politics and International Relations with research interests largely in Criminology, International terrorism and corruption in war-torn contexts. 'Senior lecturer in Youth Works with research interests on youth justice, culture, identity and belonging. ${ }^{d}$ Lecturer in Psychology with expertise on mental health

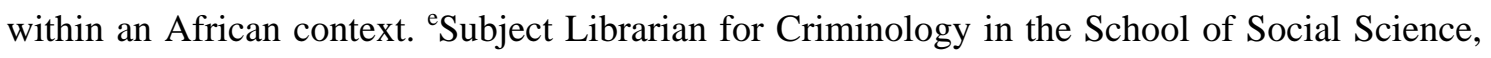
Humanities and Law. ${ }^{\mathrm{f}}$ Research Assistant. 


\title{
Community perspectives of former terrorist combatants, militants and reintegration programmes in Nigeria: A systematic review
}

\begin{abstract}
Community perspectives of repentant terrorist combatants and militants alongside the trust accorded reintegration programmes are important for successful reintegration. This review attempt to fill a significant gap through the synthesis of evidence on community perspectives of interventions adopted to foster reintegration of former terrorist combatants and militants in Nigeria. Six databases including the International Bibliography of the Social Sciences, Applied Social Science Index and Abstracts, Web of Science, Scopus, Proquest and EBsco were searched. Eighteen studies met the inclusion criteria. Informed by the principles of thematic analysis and conceptual framework of synthesis, five themes emerged: (1) Design of reintegration programmes devoid of community consultation; (2) Scepticism towards the sincerity behind monetizing rehabilitation and reintegration programmes; (3) Resistance towards reintegration due to perceived favourable incentives provided to repentant combatants; (4) Lack of confidence in the genuine repentance of former repentant combatants; and (5) Lack of confidence in government's reintegration programme. The review recommends randomised controlled trials which incorporate context-specific community-centred interventions to encourage successful reintegration.
\end{abstract}

Keywords: community; desistance; former terrorist combatants; reintegration; reintegration intervention; Nigeria.

\section{Introduction}

Reintegration of former militants and terrorist combatants is an issue of global concern for criminal justice systems. According to the UK Home Office Report (2019), there are approximately 259 people arrested for terrorism related offences in the UK of which $37 \%$ were released under investigation with or without bail while a further $34 \%$ resulted in a charge which implies reintegration upon subsequent completion of their sentence. In Nigeria, the government announced a total of 1,400 Boko Haram suspects released into 
society following their repentance (Adibe, 2020). The reintegration of combatants can thus assist to terminate conflicts.

Disarmament, Demobilization, and Reintegration (DDR) programmes aimed at reintegrating ex-combatants back into society have been multifaceted and there seems to be growing interest in around the world on community-based activities in post-conflict settings (McEvoy and Shirlow, 2009; Kaplan and Nussio, 2015). However, a growing body of literature has often tended to focus on the combatant's deradicalization and the rate of recidivism as a yardstick for determining successful reintegration of former terrorist combatants or militants (Barelle, 2015; Barkindo and Bryans; 2016; Koehler, 2016). Governmental reintegration programmes aimed at preventing ex-combatants from offending include diverse approaches such as financial subsidies, monitoring conducted by security agencies, occupational training and education. Prior studies by Blattman (2009) on Uganda, Gilligan et al. (2013) relating to Burundi and Phayal et al. (2015) on Sudan have explored some of these approaches. However, the significant focus on combatants alongside recidivism tend to downplay the role of the extant community to which the combatants will be reintegrated. Kaplan and Nussio (2016) argue that while the rate of recidivism plays an important role of countering terrorism, the risk posed concerning whether former combatants have been able to successfully reintegrate back into the society is more significant.

Clubb and Tapley (2018, p.6) highlight a better reintegration by extending deradicalization programmes to include communal 'attitudes and behaviour'. This assertion provides a significant contribution which goes some way to address the need to recognise community perspectives within the context of Nigeria. Yet there remains a gap concerning community perspectives of former terrorists, militants and reintegration 
programmes in Nigeria. This study builds upon the concept of reintegration, and community perspectives of, interventions using a systematic review approach.

\section{Background}

Historically, Nigeria's has been marred by series of conflicts which borders on ethnoreligious disputes, political agitation and a series of coups which eventually resulted in the country's transition to a democratic system in 1999. Central to these conflicts are the Niger Delta Militancy and the Jama'tu Ahlis Sunna Lidda'awati wal-Jihad (People Committed to the Propagation of the Prophet's Teachings and Jihad) - also popularly referred to as Boko Haram (Ike, 2018). While the reasons for agitations are not linear, the core reasons for the Niger Delta Militants concern the struggle over the control of resources and the restoration of polluted land as a result of oil exploration (Etekpe, 2013). Despite the region's immense contribution to the bulk of federal revenue, there is limited benefit directly accrued to the Niger Delta regions. As Koos and Pierskalla (2016) argued, wealth from the regional resources did not trickle down to the population, and the inhabitants, mostly fishermen, abandoned their occupation due to the high level of environmental degradation.

These levels of injustice and unresolved grievances predictably culminated to agitations through the form of militancy and intense vandalism of oil pipelines. This resulted in a depletion of oil revenue. In January 2006, Nigeria lost approximately 211,000 barrels of crude oil daily, which equals $8.4 \%$ of the country's export of 2.6 million barrels (Olusola, 2013). To address these agitations, former President Olusegun Obasanjo relied on intensive militarization and aggression as a means of managing the conflict. However, Obasanjo failed to achieve sustainable peace. Recognising the limitations of the previous administration, late President Umaru Yar'adua initiated an 
amnesty programme which aimed to encourage militants to desist from violence by relinquishing their arms and ammunition to the government in exchange for skills acquisition, payment of stipends and reintegration into the extant community (Adebayo \& Matsilele, 2019). The DDR initiative met with a reduction in violence and militancy operation in the region as seen in the increased oil production in the region.

Nigeria was beginning to enjoy bouts of peace following the abatement of violence in the Niger Delta region, until the emergence of Boko Haram. According to the Global Terrorism Index report (2019), Boko Haram is ranked the fourth deadliest terrorist groups in the world. The group is also known to be responsible for over 30,000 deaths as a result of terrorism (Institute for Economics and Peace, 2019). Moreover, Boko Haram has been integral to the displacement of over 2.6 million people and is notorious as the most dreadful Nigerian insurgent group (Chinonso, 2018).

Simply detaining terrorist combatants indefinitely or executing them are no longer viable options. It is against this backdrop that new approaches towards deradicalization and the reintegration of repentant Boko Haram suspects and militants becomes unavoidable due to its ability to encourage desistance and reduce recidivism. In 2020, an estimated 1,400 repentant Boko Haram insurgents were released and resettled back into the community (Adibe, 2020). While these are laudable, it raises a number of concerns about the transparency of the selection process used for those being released, and the capability of the Nigerian reintegration programmes such as Operation Safe Corridor to effectively screen the combatants to ensure they pose minimal or no threat to the host communities. Central to these concerns are the community perspectives on these reintegration programmes and the resettlement of repentant terrorist combatants or militants. So far, a synthesised review of existing studies addressing this specific issue is 
absent. This may hinder the viability of ensuring successful reintegration of the repentant Boko Haram suspects into extant communities.

Previous reviews seem to be too broad in scope, often dominated by Western case studies and lack a context-specific understanding of the Nigerian context (Grip \& Kotajoki, 2019). Although the review conducted by Grip and Kotajoki, (2019) provides a thorough investigation of the topic, it fails to explore or synthesise the Nigerian community perspective of the interventions /approaches adopted to reintegrate former combatants and its likelihood to improve reintegration. As a result, the recommendations only partially appraise the likelihood of the success of such Nigerian reintegration programmes. Of the two previous Nigerian studies Grip and Kotajoki (2019) included in their study, one mainly focused on a comparative analysis of peacebuilder's perceptions in comparison with that of the former Boko Haram members on the motivations for joining Boko Haram (Botha \& Abdile, 2017). The second study conducted by Deckard, et al. (2015) focused on rebellion and religiosity in Nigeria considering Boko Haram in the radical tradition. None of these studies explored specific community perspectives towards these interventions hence underscoring the critical need for the present review.

Similarly, existing policies on reintegration have tended to place less emphasis on the host community to which the deradicalized will be reintegrated. Studies tend to suggest that the fear of reprisal from both the community and the terrorist organization might increase the risk of former combatant's recidivism and re-involvement in terrorism and criminal activities (Riley et al., 2017; Annan et al., 2009). It is against such a backdrop that this systematic review aims to identify and synthesise community perspectives on existing interventions aimed at reintegration in Nigeria. In so doing, the synthesis will also draw on ex-militant and repentant terrorist combatants' including an affiliate's 
perspective of reintegration programmes where appropriate. The relevance of these perspectives are geared towards the production of a more nuanced understanding providing more context-specific evidence-based results intended to inform policy and practice in improving the reintegration of former combatants and militants into the society while also mitigating against the chances of recidivism.

The adoption of a systematic review is of added value and contribution where an assessment of a precisely defined subject will be helpful (Ader and Mellenbergh, 2008). As Marsden (2015) argues, reintegration entails a specific case and country contextspecific approach. Thus, as an approach, systematic reviews have been used in specific case studies and countries including Canada (Godin, et al., 2015). Applying systematic review methods to literature searches help improve the quality of review synthesis that provides a less bias and a more comprehensive set of studies to examine. In general, what is systematic about our review on community perspectives is that it allows for a less bias, reproducible and explicit attempt to identify all documents that meet an already predefined eligibility criteria for inclusion in the review (Higgins and Green, 2011).

Schuurman's (2018) recent review of 2,552 articles between the period of 2007 and 2016, found qualitative studies dominated research on terrorism. According to the review, 78.1 percent of the articles studied did not include the use of any statistical analysis and just two studies which amounted to $0.08 \%$ adopted methodologies aimed at clinical assessment (Schuurman, 2018). Based on an initial scoping exercise conducted prior to the present systematic review, similar trends were identified within the content of Nigeria. However, as one of the primary aims of the systematic review is to inform policy, focus was accorded to only studies including empirical studies and the adoption of a wholly quantitative approach was not deemed appropriate for this review. 
An understanding of community perspective of former terrorist combatants in Nigeria may provide insight in improving reintegration being the most populous country in the African continent with a population of over 200 million.

\section{Rationale for the focus on Nigeria and the inclusion of ex-militants}

This review sought to focus on the Nigerian context due to the specific case of Boko Haram and Niger Delta militants. As argued by Marsden (2015), reintegration processes are extremely context dependent. Pagano and Aviles (2020, p.4) also contend that 'Political, cultural, socio-economic, historical, psychological, and ethnic variables relevant to each conflict can all mould the success or failure' of a reintegration programme. Undertaking a Nigerian context-specific review will better inform the recommendations for improvement to existing reintegration programmes and/or the policy directives for future programmes.

Concerning the inclusion of militants, it is acknowledged that although Boko Haram and Niger Delta militants share different ideologies, however, the similarities rest on the adoption of programmes including Operation Safe Corridor and amnesty in fostering reintegration. In addition, DDR programmes are key aspects of post-conflict peacebuilding processes and reintegration. The success of DDR is mostly attributed to its ability to maintain sustainable peace and the Nigerian DDR programme had been in existence since 2009. This provides an ample opportunity to synthesise existing perspectives on the programme and its perceived inability to achieve permanent sustainable peace.

\section{Study selection and analysis}

\section{Protocol}


The systematic review adopted the protocol style by the Campbell Collaboration database in compliance with the stipulated guidelines of the Preferred Reporting Items for Systematic Reviews and Meta-Analyses (PRISMA, 2009).

\section{Eligibility Criteria}

The following criteria were employed to determine the inclusion of this study: (i) The design which includes reintegration programmes and public engagement programmes, (ii) Studies that have explored community perspectives on interventions in the form of amnesty programmes, educational programmes, community centred faith-based interventions or any other forms of intervention geared towards reintegration; (iii) Studies including Nigerians aged 18 years and above irrespective of religion; (iv) Quantitative, qualitative or mixed-method studies that report community perspectives of reintegrating former combatants to the public, the community perceptions of the reintegration programme and its implications for reintegration.

In the review, we excluded studies which did not focus on community perspectives of reintegration interventions of former terrorist combatants and/ or exmilitants; (ii) Studies in which the population is non-Nigerian; (iii) Studies that are not published in English nor contain English language translations.

\section{Search strategy and the extraction of data}

The search sources adopted for this review include the searches on the following six electronic databases: International Bibliography of the Social Sciences (IBSS), Applied Social Science Index and Abstracts (ASSIA), Web of Science (WoS), Scopus, Proquest, and EBsco. The search covered published articles and reports between 2009 and May 2020 as that marked Nigeria's first attempt of introducing amnesty to the militants. The 
design of the search terms included the 'reintegration of former terrorist combatants', reintegration of ex-militants in Nigeria', 'interventions' and 'combatant' or 'reintegration' and 'Nigeria', 'ex-militants' and 'reintegration', or amnesty' and 'Nigeria', 'reintegration interventions in Nigeria' 'community perceptions' and 'reintegration interventions' and 'formers combatants' or 'ex-militants', and 'Nigerian reintegration programmes'. In total, 844 studies emanated from the search and of these, 507 were removed following screening for duplication and relevance. The title and abstract of the 18 papers included for the study were screened for their relevance and assessed to ensure they met the inclusion criteria of the study (See appendix for study characteristics). Of the 18 studies, thirteen explored interventions such as amnesty and community perceptions aimed at reintegrating former repentant militants and community perspectives of these interventions. The other five addressed interventions and community perceptions aimed at reintegrating former Boko Haram combatants or persons associated with the group by agencies such as operation safe corridors.

\section{Data synthesis}

The review adopted the conceptual framework of synthesis as enunciated by Torraco, (2005). Each source was critically evaluated and analysed for major strengths, weaknesses, themes, and critical gaps using the synthesis matrix. The synthesis was conducted through a four-stage approach: (1) relevant literature search, (2) identification of key ideas and elements, (3) organization of key ideas and elements, and (4) synthesis of the information found to develop potential new research intervention. More specifically, the study adopted an 'index card method' in order to identify and organise key elements and ideas contained in stages 2 and 3. In Stage 4, each category of the organized ideas were re-arranged into: (a) a logical flow of information, (b) compare and 
contrast (c) critique where necessary, and (d) postulate a proposed alternative model for future research intervention. It was envisioned that the synthesis would inform policies aimed at improving the reintegration of former repentant Boko Haram members and exmilitants into the community.

\section{Quality assessment and mitigating bias}

In order to ensure quality and avoid potential risk of bias, the study adopted the QualSyst tool (Kmet, et al., 2004). This tool served as standard quality assessment criteria to evaluate primary research papers from a variety of fields. Two evaluators independently conducted an assessment on the risk of bias and where potential conflict existed, this was resolved by a third assessor.

\section{Results}

[Insert figure 1 here]

Figure 1 showing a flow chart of the systematic literature review process

\section{Themes}

Based on the review and synthesis, the following major themes emerged: (1) Design of reintegration programmes devoid of community consultation; (2) Scepticism towards the sincerity behind monetizing rehabilitation and reintegration programmes; (3) Resistance towards reintegration due to perceived favourable incentives provided to repentant combatants; (4) Lack of confidence in the genuine repentance of former repentant combatants; and (5) Lack of confidence in government's reintegration programme. These will be covered in turn.

\section{Design of reintegration programmes devoid of community consultation}

A common theme from 13 of the 18 synthesised studies was the perceived sense of a top- 
down approach in designing rehabilitation and reintegration programmes (Adebayo \& Matsilele, 2019; Ikoh \& Ukpong, 2018; Onyima, 2017; Tobor, 2016; International Alert/UNICEF Nigeria, 2016; Felbab-Brown, 2018; Okoli-Osemeni, 2018; Centre for Democracy and Development, 2017; Onyima, 2017; Etekpe, 2013; Okurebia \& Daniel, 2013; Hassan and Tyvoll, 2018; Nwanze, Obingene \& Nieze, 2018). Communities felt a lack of ownership on the process and thought that the programmes did not reflect their norms, values or opinions regarding reintegration. As one of the studies' participants states:

The government did not see the need to resolve the lingering crises from the root by addressing issues of marginalization, environmental degradation and widespread poverty in the region. The reintegration of the ex-militants and the entire amnesty programme was faulty in that it employed a top-bottom approach of conflict resolution that did not take into cognisance inputs from members of the community on how to permanently resolve the crises. This process is simply branch - cutting; the root is still there, after a while, the branches will sprout again (Mr Lulu - in Adebayo \& Matsilele, 2019, p.152).

The general sense was that outsiders were invited to design programmes without taking communal aspects and the variances of the ways in which grievances and reintegration were achieved. These outsiders' contexts were likened to measures that were cut and pasted from Western societies without necessarily adapting it to the Nigerian context and thus failed to consult with the host communities where the repentant combatants would be reintegrated. Similarly, another study reported the concerns of a traditional chief who opined that:

The importance of cleansing the land is significant especially when murder, rape and blood oath is involved. The amnesty programme of the Federal government, however, disregarded the 
roles of the community. No ritual or reconciliation was made. Victims of the conflicts who suffered in the hands of the militants were not assisted in any way and the offender did not show any remorse (Onyima, 2017, p.91).

The feeling of alienation breeds multifaceted aspects of frustration, resentment and stigma towards the repentant combatant. The traditional norms and values which foster community cohesion were undermined which resulted in disparity between the community and the amnesty programme thus failing reintegration. Similarly, this feeling of non-consultation was highlighted among the militants who were beneficiaries of the amnesty and reintegration programmes. The study conducted by Tobor (2016) which comprised of 20 ex-militants from the Urhobo speaking tribe enlisted in the amnesty programme of the Niger Delta region highlighted this finding. It found that there was a perceived sense that the agencies that implemented the amnesty programme 'failed to take into consideration the significant function of the cultures of the Niger Delta communities' (Tobor, 2016, p.17). Tobor (2016) study also found that the failure to consider culture, the grievances of militants and community views into account contributed to the inability to socially and economically reintegrate ex-militants (Tobor, 2016). The short-term deficiency may encompass an immediate resort to violence by the ex-militants, whilst the long-term impact may include the continuous hindrance of social, political and economic develop of the country (Tobor, 2016).

Alienation of the community serves to exacerbates the perceived lack of accountability The review found that studies highlighted concerns on the difficulty in discerning accountability for acts perpetrated by former combatants (Felbab-Brown, 2018; Hassan \& Tyvoll, 2018; Onyima, 2017; International Alert/UNICEF Nigeria, 2016) and the government (Nwanze et al. 2018). A female participant in Hassan and Tyyoll's (2018: 17) study stated that: 
We are prepared to cooperate with whoever is ready to prosecute Boko Haram insurgents; we want to be given the opportunity to present our case before a court of law because we lived with them in Bama, we witnessed the atrocities they committed against us and other women but unfortunately nobody has come to ask us what happened.

A sense of retributive justice is seen to shape the participant's construct. The perceived sense of the inability to be part of a process that ensures accountability is seen to frustrate attempts at reconciliation and reintegration. This lack of accountability is also perceived to fuel more violence within the context of the Niger Delta. For instance, Nwanze et al (2018, p.80) study highlights community participants concern when one of the youth leaders contended that:

Most of our youths usually join pipeline vandalization as a way of avenging the wickedness and neglect of the oil companies and government and the brutality of the military deployed to the company. They believe that vandalizing oil installations will causes damage and expenses to the companies and the government. So they join in perpetrating pipeline vandalization as a way of revenge.

It could be deduced that the inability to resolve deep-seated grievances perpetrated by some government officials through the involvement of the community often tend to degenerate into other conflicts as seen in the perceived quest by the youth to undertake private/rough justice.

\section{Scepticism towards the sincerity behind monetizing rehabilitation and reintegration}

\section{programmes}

In nine of the 18 studies, a notable finding was the sense that monetization or the granting of amnesty could not provide a long-term solution to the problem (Ebiede et al, 2020; 
Adebayo \& Matsilele, 2019; Ikoh \& Ukpong, 2018; Felbab-Brown, 2018; Centre for Democracy and Development, 2017; Onyima, 2017; Iwilade, 2017; Raimi, Bieh \& Zorbari, 2017; Etekpe, 2013). These views resonated regardless of the group. For instance, one of the participants who was a community leader in Adebayo and Matsilele's (2019, p.153) study opined that:

The moment money was included in the amnesty programme, I knew it would not last, and I immediately doubted the government's sincerity. How do you sustain the doling out of money? For how many years? What happens when a new government comes into power and stops giving out money? Have you noticed that politicians who have stolen billions from the public's purse have found a way of including their children and wards in the scheme? Once the money is involved, everyone would want a share, and the real issues would be swept under the carpet until a future time. That is the sad reality of the amnesty programme, the monetization is unsustainable. It was a bad idea (Bishop Okpokori).

Similarly, it was found that the granting of monetary incentives served to exacerbate the tendency of repentant militants to move beyond the amnesty programme due to fear that such financial support would be withdrawn. This concern was echoed by DDR officials, community members and the repentant militants. For instance, one DDR official who was a participant in the study conducted by Ebiede et al., (2020, p.7) noted that:

If you look at it, the $\$ 65,000$ (US $\$ 400$ ) is more than the minimum wage. Even for those who have gone through reintegration training, efforts are being made to get them employment. Because some of them are not graduates and the skilled labour can hardly really pay that much, they are not willing to take some of the jobs because the monthly stipend will be paid, so it makes no sense to 
accept a job that will pay less than the monthly stipend. This is a disincentive for most of them to take up regular employment.

This monetary incentive has also been recorded as a basis for abuse, where persons including prisoners who might not necessarily be a militant, claims a position either as a perceived right to economic benefits or through manipulations in order to be included in the programme (Iwilade, 2017). Despite the resentment towards the use of financial incentive as a basis of addressing underlying issues, however, only one study seems to suggest that the majority of its participants supported the provision of ex-militants, who passed through the non-violence/rehabilitation training, some compensation package and allowance in exchange for their commitment to avert their return to violence (OkoliOsemeni, 2018).

Mixed feeling on the effectiveness of monetizing reintegration programmes

In addition to the perceived scepticism towards monetization, some studies highlighted perceptions of its effectiveness due to the surrendering of weapons by the militants (Nwanze, et al., 2018) while others emphasised perceptions of its ineffectiveness (Adebayo and Matsilele. 2019; Umoh, et al., 2019 Felbab-Browne, 2018; Raimi, Bieh \& Zorbari, 2017; Iwilade, 2017; Touitou, 2016; Ikoh \& Ukpong, 2013). Concerning the former, a study comprising of interviews with ex-militants and the former coordinator of the Presidential Amnesty programme perceived DDR and amnesty programmes as effective in increasing oil production and reducing the vandalism of oil pipelines (Nwanze, et al., 2018). Whilst the study reported interviews with repentant militants, it was unclear from the data as to whether they perceived the programmes to be effective as secondary sources, such as newspapers that were drawn on as a basis for determining efficacy. 
Another study relying on survey of 400 youths who are main stakeholders of the Niger Delta crises reported that respondents felt it was effective at achieving economic progress for Nigeria, however, the programme appeared marred by corruption (Touitou, 2016). This was partly because the programme was deemed to merely enrich the militants rather than the entire youth population of the Niger Delta (Touitou, 2016). In another study including 293 surveyed ex-militants, it was found that the comprehensive implementation of the amnesty programme was feared due to the lack of trust and confidence in the politicians handling the implementation alongside the failure of previous governmental empowerment programmes (Ikoh \& Ukpong, 2013). The study also recorded that these perceptions informed the decision of some militants to withhold their ammunitions alongside the outright rejection of the amnesty (Ikoh \& Ukpong, 2013).

The commodification of violence through the retention of arms is seen to constitute some of the limitations of the amnesty programme in the Niger Delta region since one of the criterions for being qualified for the programme is the surrendering of arms and ammunitions. This seems to be reflected by Ikoh and Ukpong (2013) that found that respondents believed the amnesty would not result in the overall development of the Niger Deltan region. Similar findings were recorded in another study comprising 320 repentant militants which found that the inability to address issues such as inadequate infrastructure, adverse human development, poverty and environmental degradation strongly undermined the amnesty programme's ability to achieve sustainable peace (Raimi et al., 2017). The study also recorded $83 \%$ of the respondents who expressed disagreement on the amnesty programme addressing the main issues that fuelled violent agitations in the Niger Delta (Raimi et al., 2017).

Resistance towards reintegration due to perceived favourable incentives provided to repentant combatants 
For seven of the studies, a common theme was the perceived resistance towards reintegration due to the preference of repentant Boko Haram needs above the host communities' in terms of development and opportunities (Adebayo and Matsilele, 2019; Hassan and Tyvoll, 2018; Mahmood and Ani, 2018; Centre for Democracy and Development, 2017; Onyima, 2017; International Alert/UNICEF Nigeria, 2016; FelbabBrown, 2018). The perceptions held in these studies asserted the disregard for the reintegration programmes. For instance, in the study conducted by Hassan and Tyvoll (2018, p.19) comprising of 1200 respondents that have experienced Boko Haram violence, one of the respondents opined that:

For us to agree on any reconciliation or dialogue, our livelihoods have to be resuscitated; we lost all our properties in the insurgency and we see de-radicalised Boko Haram member with assets provided for him to restart his life, while we the victims, who lost everything, have not received any help: we cannot accept that.

Similarly, the study conducted by the Centre for Democracy and Development (CDD, 2017) sought to explore the disposition of participants towards post-conflict reintegration of repentant ex-Boko Haram combatants. The participants comprised of interviews and focus groups conducted with purposively selected ex-Boko Haram combatants, survivors of the group's insurgency, the civilian joint task force, members of the Nigerian military, hunters, camp officials, religious leaders, security agents students, academics, primary school teachers and development workers. Participants were drawn form 12 communities in Bornu state and 10 communities in Yobe state. The CDD (2017) study found that the communities' survivors challenged the attention directed at resettling former Boko Haram perpetrators with the concern that a similar level of attention is not given to victims who suffered from Boko Haram attacks. The study also found that community members 
perceptions of Operation Safe Corridor rehabilitation and resettlement of repentant Boko Haram are seen to:

be unfair to the victims who remain displaced from their homes, disempowered and struggling to survive without adequate help [... while] the rehabilitation scheme of the military for the excombatants, entails keeping them in a safe location, feeding them, deradicalizing them and developing a scheme for empowerment through the Operation safe Corridor (Centre for Democracy and Development, 2017, p.12).

These findings appear disheartening from the context of the participants as there was a perceived imbalance on the priority of offenders over those who live on the right side of the law.

Felbab-Brown's (2018) study also recorded similar resentment expressed by community members on the rehabilitation, deradicalization and reintegration programmes offered to persons previously associated with Boko Haram. The study comprised of 69 interlocutors, including current and former Nigerian government officials, victims' groups' representatives; women and children who have exited the deradicalization camp, representatives of Nigeria's business community. There were widespread perceptions among displaced communities and the victims of the perceived limited and unequal access to government benefits. This demonstrates a feeling of misplaced priority which tends to place importance on rehabilitating those perpetrating violence as opposed to the communities who are victims of the atrocities committed by Boko Haram. As one community member in Felbab-Brown's (2018, p.92) study noted: 'Why are you rehabilitating former Boko Haram members when thousands of young men did not join the group? Those who did not join should be receiving assistance. They and we lack basic necessities and opportunities.' This manifestation stresses the moral hazard which may emerge as a result of this preferential treatment towards Boko Haram. As the 
study also found, the implication of such treatment is that if former members of Boko Haram get assistance and training through acts of defector, it may create a perceived position where others might be conditioned to think that they could easily join Boko Haram and in the event that there are dissatisfied with their experiences, they could easily surrender to the government and get employed (Felbab-Brown, 2018).

\section{Lack of confidence in the genuine repentance of former repentant combatants}

Among 12 of the 18 synthesised studies, most respondents perceived stigmatization and a lack of confidence in the genuine repentance of former apologetic combatants who were members of Boko Haram or part of a militancy (Ebiede et al., 2020; Adebayo \& Matsilele, 2019; Hassan \& Tyvoll, 2018; Felbab-Brown, 2018; Nwanze et al., 2018; OkoliOsemeni, 2018; Centre for Democracy \& Development, 2017; Iwilade, 2017; Onyima, 2017; International Alert/UNICEF Nigeria, 2016; Etekpe, 2013; Okurebia \& Daniel, 2018). The lack of confidence implies the expression of doubt in the ability of excombatants to truly reform. This was construed from various perspectives which included personal experience, economic gains, group allegiance, potential relapse and recidivism. For instance, the study by CDD (2017) also found that because community members have been traumatized by the atrocities perpetrated by Boko Haram, the majority expressed doubt concerning the genuine repentance of Boko Haram members. In Felbab-Brown's (2018, p.108) study, community members including members of the civilian joint task force expressed concerns that 'those who defected did not do so out of genuine "repentance," but merely because "they were hungry in the bush". Economic gain is equated with pretence which is construed as being inadequate for obtaining the community's leniency the genuine belief in the repentance of combatant.

Similarly, a participant in Iwilade $(2017$, p.25) while explaining the tendencies of exmilitant to continue in oil theft highlighted concerns that: 
No matter how well the amnesty is organized [there will be discontent]. The problem is you just cant's control these boys. They are complaining about [ex-militant commanders] and their billion contracts. They just want to make their own money too [...] At least you have heard of Arepo [a small town in Ogun State, outside the Niger Delta where a fire incident from a vandalized pipeline resulted in the death of hundreds of people]? Do you think it is Yoruba people who did that? It's the same boys! They are taking laws into their hands because they know that with amnesty there is no real JTF [Joint Task Force] again to catch them.

The quest for 'economic gains' is seen to be construed in negative light and as a factor limiting the genuine repentance of former militants. This trend was also corroborated in the study of Okoli-Osemeni, (2018) and Nwanze et al.'s (2018, p.80) study where in the latter, a militant interviewed stated that:

Destruction of oil installations especially pipeline vandalization is the most effective method to engaging the government $[\ldots]$ This is because, when we destroy oil pipelines for example, we can get money to take care of ourselves by selling the oil gotten form the pipeline, we can also get money to buy ammunitions to fight back the JTF.

The excerpt also highlights a perceived 'greed' on the part of the militants whose ambition is not necessarily to be reformed for financial gain even if it is at the expense of national security or the loss of economic well-being of the country. 
Allegiance and being used as potential spy agents

Issues surrounding allegiance to Boko Haram and the inability to truly break free from the group formed part of the reasons why the community lacked confidence in the true repentance of former combatants (International Alert/UNICEF Nigeria, 2016; CDD, 2017; Felbab-Brown, 2018; Adebayo \& Matsilele, 2019). For instance, the CDD (2017, p.11) study found that the participants interviewed maintained that:

Those that had earlier been released served as intelligence agents for Boko Haram and made their communities susceptible to attacks. As such $[\ldots]$ they cannot be trusted.

Interestingly, this finding was only peculiar to Boko Haram and not the militants. A possible explanation for this may partly be because of the differences in community perspectives on reintegration depending on the type of conflict, actors and level of violence perpetrated. For instance, the Niger Deltan militants are often presented in a more sympathetic stance in comparison with Boko Haram due to the cause of grievances which often stem from issues of marginalization, environmental degradation and unequal distribution of resources.

\section{Fear of reoffending and crime}

Some studies further highlighted the perceived fear of relapse and recidivism of former repentant members if there were to be reintegrated back into the society (Ebiede et al, 2020; Hassan \& Tyvoll, 2018; Felbab-Brown, 2018; Onyima, 2017; CDD, 2017; International Alert/UNICEF Nigeria, 2016; Okurebia \& Daniel, 2013; Etekpe, 2013). In one of the studies, a participant commented that:

If repentant fighters of Boko Haram were to be reintegrated today into my neighbourhood, I would relocate to another area because they would later regroup and fight us again. They are repenting 
now because the condition is bad in terms of food and general welfare in the bush. (Hassan \& Tyvoll, 2018, p.24).

Similarly, the feeling of fear also permeated the majority of the participants in a study conducted by UNICEF in collaboration with International Alert in 2016. The study was designed to understand the perceptions of communities, family members, religious and traditional leaders and government stakeholders towards affected girls, women and children from Boko Haram. The study comprised of 19 focus group discussions with these stakeholders and the data collection was conducted in four internally displaced camps which have suffered heavily from Boko Haram during the period of insurgency. These are Gwoza, Bama, Dikwa and Daboa in Maiduguiri, and Borno state capital. The majority of the comments expressed from women and their children rescued from Boko Haram suggested fear and rejection. For instance, one participant who is a family member was recorded to indicate that ' ... if we accept sons/daughters of JAS [Boko Haram] ... they [the mothers] may come back to kill us' (International Alert/UNICEF Nigeria, 2016, p.15). Another was noted to opine that 'a child of a snake is a snake' (International Alert/UNICEF Nigeria, 2016, p.15). One community leader opined that when it comes to children from Boko Haram, "We believe that they would be treated nastily as it is a belief that they would inherit their parents' behaviour" (International Alert/UNICEF Nigeria, 2016, p.15). The prevailing findings from the study was that those displaced from Gwoza expressed the most intolerance and fear towards returning girls and women. The study also found that some of the returners who came with or without children were mostly safe in the internally displaced persons camps and if they attempted to return to their communities, they risked encountering grave danger.

Even among former Niger Delta militants, there was a sense of fear from the community due to economic factors such as lack of jobs, which can result in repentant militants being posed as potential suspects that engage in crime and illegal activities. For 
instance, one of the community member participants from Ebiede et al.'s (2020, p.6) study noted that:

Things are hard, even these boys (exmilitants) you see, you just see them in the community in the day, but you don't know what they are doing at night, they are the ones going to burn crude oil to make fuel and do several things in the bush, that is how many people survive.

Based on the synthesis, the identity of being a former militant, Boko Haram member or even affiliated with the terrorist group conjures a feeling of fear. This seems regardless of whether such persons have undergone rehabilitation and reintegration programme.

\section{Lack of confidence in government's reintegration programme}

The review also found that 11 studies highlighted participants lack of confidence in the governmental rehabilitation and reintegration programmes coupled with its perceived ineffectiveness on reintegration (Ebiede et. al., 2020; Adebayo and Matsilele, 2019; Felbab-Brown, 2018; Hassan and Tyvoll, 2018; Okoli-Osemeni, 2018; Ikoh \& Ukpong, 2018; CDD, 2017; Iwilade, 2017; Onyima, 2017; Okurebia \& Daniel, 2013; Etekpe, 2013). This is regardless of whether it is a group associated with Boko Haram or Niger Delta militants. For instance, in Adebayo and Matsilele (2019, p.156) study exploring interventions from both the context of the Niger Delta militants and former Boko Haram members found that:

The government's approach in both interventions was targeted at the former combatant, neglecting other members of the community. [...] What this type of intervention communicates to the members of the communities is that the former combatants are 'special' thereby unwittingly glamorising criminality.

More specifically, a respondent in their study while commenting on Operation Safe Corridor intervention opined that 'Suddenly, it is more fashionable and profitable to be a 
terrorist.' (Adebayo and Matsilele, 2019, p.156). This perceived alienation of the community and one-sided approach to reintegration correlates to the lack of confidence in the genuine intention of the governmental programme to effectively deliver successful reintegration. This is more so, as the community might be more predisposed to anger over the favouritism of the 'repentant terrorist'.

In another study comprising of 85 ex-militants, 116 respondents and 12 officials that sought to explore the constraint associated with the presidential amnesty committee implementing the amnesty programme in Nigeria reflect this concern (Okurebia \& Daniel, 2013). The study found that there was a perceived sense that the camps designated to implement amnesty lacked the capacity to ensure the reintegration of former militants because some militants were in the state of spiritual and mental rebellion against existing authority. This according to the study was further coupled with the lack of expert personnel and rehabilitation facilities to foster effective reintegration (Okurebia \& Daniel, 2013).

Within the context of the former repentant Boko Haram, it was found that in the study conducted by Felbab-Brown (2018), programmes such as the Operation Safe Corridor are perceived as dangerous, non-transparent, insincere and top-down. It was also found that the programme is resented by communities and viewed as a policy for coopting dangerous individuals and militants. Perceived 'fear of state reprisal for telling the truth' about 'so-called de-radicalised youths' were highlighted as some of the primary concerns of the communities in Hassan and Tyvoll's (2018: 24) study.

\section{Abuse by government officials}

Some of the studies highlight previous experiences of abuse at various levels as some of the reasons why the community do not trust government reintegration programmes 
(Ebiede et al. 2020; Felbab-Brown, 2018; Ikoh \& Ukpong, 2018; Okoli-Osemeni, 2018; CDD, 2017; Okurebia \& Daniel, 2013; Etekpe, 2013). For instance, the CDD (2017, p. 9) in their study concerning Boko Haram found from the interviewed participants that:

their culture, ethos and social norms have been violated by the security forces and some aid workers. [...] women have been abused, coerced or influenced with money or other resources to engage in sexual relations; some have been sexually abused.

This is also coupled with the lack of a clear strategy for reintegration that constitute one of the key shortcomings of Operation Safe Corridor (CDD, 2017). Within the context of the Niger Delta militants, there were also perceived allegations of abuse namely corruption, perpetrated by the agencies supposed to be administering the programmes and the substandard training package provided to foster reintegration (Ebiede et al. 2020; Etekpe, 2013). For instance, Ebiede et al (2020, p.9) surmised in their study that:

The contractors were generally paid by the PAP [Post-Amnesty Programme] on the basis of the number of ex-militants being placed into a programme. Many contractors appear to have abused this system by inflating the number of ex-militants that were said to have enrolled in different training programmes.

Concerning trainings, an ex-militant who was a direct recipient of the programme in Ebiede et al (2020: 8) study highlighted concerns that:

The fact is that we are facing some challenges in our training. Firstly, the people that are training us are not giving us good training [..] some days we will come for training and we will stay here for about 30 minutes and they will dismiss us to go back home. Our training is supposed to be for nine months and we have been here for four months now. In the four months, we have achieved nothing. We have not learnt anything; I can say that the four months have been wasted. 
This serves to further exacerbate the lack of confidence in the agencies and the government as such a situation may potentially give rise to the tendencies of ex-militant to resort to illicit activities thereby endangering the community. In addition, the issue of abuse was also extended to a perceived co-opting of the amnesty programme by those delivering it for their personal gains. A repentant militant in Iwilade's (2017, p.16) study commented that:

Nobody who carry gun [was an armed fighter] and wanted to participate in the amnesty was left out. In fact, people had to go about looking for people to include. Many of the commanders got slots more than the number of fighters. Even the JTF people (Soldier deployed to the region) lobbied our commanders and got people [into] the list.

Even though there was a perceived positive construct on the access to the programme, however, the lobbying for 'slots' government agencies who are at the elms of affairs in the administration of the programme highlights a sense of abuse which undermine the programme's integrity.

\section{Discussion, Conclusion and Implications for Policy}

The purpose of this review was to synthesise community perspectives of interventions adopted to foster reintegration of former terrorist combatants and militants in Nigeria. Our review highlights five key themes which will be discussed with supporting evidence from the synthesized studies and wider literature. By extension, the review aimed to fill a gap in the area that could inform a change in policy approach towards interventions aimed at reintegration. 
Firstly, the review highlights a perceived sense from the community that reintegration programmes are design devoid of government consultation with the community who are key stakeholders. (Adebayo \& Matsilele, 2019; Felbab-Brown, 2018; Okoli-Osemeni, 2018; Hassan and Tyvoll, 2018; Nwanze et al., 2018; Ikoh \& Ukpong, 2018; Onyima, 2017; CDD, 2017; Onyima, 2017; Tobor, 2016; International Alert/UNICEF Nigeria, 2016; Etekpe, 2013; Okurebia \& Daniel, 2013). This finding highlights similar concerns expressed within the literature. As Clubb and Tapley (2018) argue, the community's ideational relation to the state plays a significant role in shaping their perception toward the acceptance of former combatants. Similarly, within the context of Colombia, Kaplan, and Nussio (2016) argue on the need to recognize the role of the community in reintegration and peace building as this determines the effectiveness of reintegration interventions. Within the context of Nigeria, 'culture' and 'values' were perceived as undermined when a foreign approach is adopted as intervention to foster reintegration. This tends to degenerate to a perceived feeling of alienation which spurs a feeling that combatants are not held accountable and as such creating a void in the whole reintegration process (Felbab-Brown, 2018; Hassan \& Tyvoll, 2018; Onyima, 2017; International Alert/UNICEF Nigeria, 2016) and the government (Nwanze et al., 2018). The review finds that in its extreme manifestation such void might degenerate into a quest for retribution (Nwanze et al., 2018) which does little to improve reintegration.

Secondly, the review highlights a perceived scepticism toward the Nigerian government's genuine rationale for proffering monetary incentives to the ex-combatants/ militants as a means of fostering reintegration and rehabilitation. (Ebiede et al, 2020; Adebayo \& Matsilele, 2019; Ikoh \& Ukpong, 2018; Felbab-Browne, 2018; CDD, 2017; Onyima, 2017; Iwilade, 2017; Raimi, Bieh \& Zorbari, 2017; Etekpe, 2013). This criticism tends to breed a feeling that those who are not members of Boko Haram or even take up 
arms, like the militants, are less worthy of governmental attention under the programme. As such, reintegration programmes were perceived as legalising criminal acts, rewarding violence, giving criminals power, fame, money and glorifying recklessness while the innocent law-abiding citizens suffer as victims and remain unemployed with little financial opportunities (Adebayo and Matsilele, 2019; Felbab-Brown, 2018; Onyima, 2017). This alludes to other literature including Unabia (2011) who argues that amnesty programmes which offer cash as incentives as a model for restive youth are fragile with limited chances of optimal success. Although the use of amnesty has often been presented in a positive light for reducing violence in the Niger Delta region (Nwanze, Obingene \& Njeze, 2018; Touitou, 2016), this victory seems construed as one-sided by improving government revenue and enriching the perpetrators at the expense of communal sufferings (Onyima, 2017; Touitou, 2016).

A third finding from the review was a sense of community resistance to reintegration due to perceived favourable incentives given the repentant combatants (Adebayo and Matsilele, 2019; Felbab-Brown, 2018; Hassan and Tyvoll, 2018; Mahmood and Ani, 2018; CDD, 2017; Onyima, 2017; International Alert/UNICEF Nigeria, 2016). This reinforces a heightened mood of resentment and expressions of dissent towards the government provision of economic support, training and financial packages to former combatants while relegating the support to the extant community. Thus, these findings highlight similar concerns by Marsden (2015) who argues from the context of the UK that the community concerns of a balanced treatment from the government is integral in conceptualizing successful reintegration. Ogege (2011) also contends that the concentration of governmental focus on offenders, including exmilitants, without taking into consideration the well-being and development of the entire community may prove to be fatal. Kingma (1997) explored similar reintegration contexts 
in the 1990s and found that the provision of cash stipends and economic assistance to excombatants, fostered resentment from the community towards these former fighters as the latter were seen as receiving unjustified rewards in a resource limited environment. Within our review, a possible explanation for this, may be partly informed by the poor channel of communication between the government and the community which tends to further exacerbate communal resentment.

The fourth finding reveals a perceived lack of confidence in the genuine repentance of former combatants (Ebiede et al, 2020; Adebayo \& Matsilele, 2019; Hassan \& Tyvoll, 2018; Felbab-Brown, 2018; Nwanze, Obingene \& Nieze, 2018; OkoliOsemeni, 2018; CDD, 2017; Iwilade, 2017; Onyima, 2017; International Alert/UNICEF Nigeria, 2016; Etekpe, 2013; Okurebia \& Daniel, 2018). This finding is consistent with other literature (Riley et al., 2017; Annan et al., 2009) including the context of the Trish Republican Army (McEvoy, 1998). Our study further finds that such 'fears' were partly informed by the sense that 'allegiance' to a cause or ideology of certain groups may make it difficult to truly reform. For instance, there was a perceived resistance to former Boko Haram combatants because communities feared they might act as spies and informant in triggering more violence (Adebayo \& Matsilele, 2019; Felbab-Brown, 2018; CDD, 2017; International Alert/UNICEF Nigeria, 2016). However, a noticeable difference in community perspectives is seen in terms of the type of conflict and actors as the Niger Delta militants were not construed as spies. Rather, economic gains due to the nonprovision of jobs or depletion of the amnesty incentives were seen as some of the factors that could trigger the fear of their potential recidivism (Ebiede et al, 2020; Onyima, 2017; Okurebia \& Daniel, 2013; Etekpe, 2013). An explanation for this may be partly informed by the reward that emanates from engaging in violence. As Heimer (2001) argues, when 
the condition of uncertainty arises, benefactors of an intervention (programmes) may tend to align with the option they are already familiar with that includes violence.

The fifth finding from our review highlights a lack of confidence in governmental reintegration programmes (Ebiede et. al., 2020; Adebayo and Matsilele, 2019; FelbabBrown, 2018; Hassan and Tyvoll, 2018; Okoli-Osemeni, 2018; Ikoh \& Ukpong, 2018; CDD, 2017; Iwilade, 2017; Onyima, 2017; Okurebia \& Daniel, 2013; Etekpe, 2013). Instances of this spans from the lack of transparency in the reintegration interventions (Felbab-Brown, 2018) to corrupt practices of those administering the intervention (Iwilade, 2017; Ebiede et al. 2020) and perceived favouritism of the alleged 'repentant' combatants over the community (Adebayo and Matsilele 2019, p.156). Previous literature has contended and argued that when community lacks faith in government reintegration it tends to limit the efficacy of such programmes (Marden, 2015).

Based on the findings, it is recommended that the Nigerian government should build confidence in reintegration programmes through increased transparency and participation in order to reduce reliance on top-down programmes that are implemented by the government. In addition, a transparent process which ensures community members are allowed access to vital information could also build 'trust' and positively contribute to successful reintegration. This is because by ensuring their access, the needs of all community members could be identified through effective dialogue between government representatives and local communities. This will potentially spur a bottom-up approach to address issues of reintegration within a post-conflict context. As Tobor (2016) claims, involving and engaging indigenous members in the affairs of communities could play a role in increasing the quality of decision making, fairness and legitimacy.

Concerning the fear of recidivism, it is recommended that the government should make a concerted effort towards a sustained engagement and advocacy work with the 
communities affected to ensure trust-building and aversion of fear against the potential risks of repentant Boko Haram and militants engaging in crime. To achieve this, emphasis could be particularly provided on the engagement of traditional, community and religious leaders on the identification and resolution of challenges likely to be faced by the target community in accepting repentant combatants.

Finally, one of the implications of our review was the sense that being a lawabiding citizen seems unprofitable due to the perceived relegation of the victims including the community in favour of ex-militants. While 'deradicalization' and transformation of the 'repentant' combatant might see a reduction in attacks which translates to perceived success for the government, such a success is not without its limitations. From a tactical perspective it could be construed as a short-term success as hostility and non-acceptance of the community towards the repentant combatant may spur a feeling of alienation and subsequent reversion to recidivism. However, from a strategic long-term perspective, the adoption of a robust approach which takes into context the needs of all stakeholders may yield more positive results which will not be perceived as a one-sided programme that benefit the government. It may also prove useful in dispelling the myth that 'crime pays' and as such limiting the occurrence of further new breeding of crime.

There are several limitations associated with our review which are acknowledged. Firstly, the Nigerian focus of the review does limit to some extent the conclusion which can be drawn and its applicability to other context. Although assumptions cannot be made based on geographical or countries comparison, however, it does illuminate broader concerns about community participation in post-conflict resolutions. Secondly, attempts were made to contact authors whose paper could not be obtained during the searches but had limited success. 
However, this systematic review contributes to the literature and policy. Findings from this systematic review have important implications for the Nigerian government reintegration policy and practice as well as for post-conflict resolution and reintegration programmes and intervention more widely. Themes identified in the review, could be used to inform future research studies which builds on the study's recommendations for a community informed intervention, and tested through a randomised control trial with the aim of dispelling the fears of genuine repentance of former Boko Haram members in order to aid successful reintegration. 
References

Adebayo, J. O. \& Matsilele, T. (2019). Nigerian experience with post-conflict peacebuilding: Examining operation safe corridors and the Niger Delta amnesty programme. Journal of African Union Studies, 8(3), 135-156.

Ader, H.J., Mellenbergh, G.J., \& David, J. (2008). Hand. Advising on Research Methods: a consultant's companion. Johannes van Kessel Publishing.

Adibe, J. 'Should Nigeria have Released Boko Haram Suspects?'. The Conversation, 20 February 2020.

Annan, J., Brier, M., \& Aryemo, F. (2009). From "rebel" to "returnee": Daily life and reintegration for young soldiers in Northern Uganda. Journal of Adolescent Research, 24(6), 639-667.

Barkindo, A., \& Shane, B. (2016). De-Radicalising prisoners in Nigeria: developing a basic prison based de-radicalisation programme. Journal for Deradicalization, 7, $1-25$.

Barrelle, K. (2015). Pro-integration: disengagement from and life after extremism. Behavioral Sciences of Terrorism and Political Aggression, 7(2), 129-142.

Biggar, N. (2002). Peace and justice: A limited reconciliation. Ethical Theory and Moral Practice, 5(2), 167-179.

Blattman, C. (2009). From violence to voting: War and political participation in Uganda. American Political Science Review, 103(02), 231-247.

Botha, A., \& Abdile, M. (2019). Reality versus perception: Toward understanding Boko Haram in Nigeria. Studies in Conflict \& Terrorism, 42(5), 493-519.

Centre for Democracy and Development, (2017). Prospects for Transitional Justice Initiative in North East Nigeria. CDD http://cddwestafrica.org/wpcontent/uploads/2017/09/Transitional-Justice-In-North-East.pdf (Accessed 25 May 2020).

Chinonso, A. A. (2018). Multi-national joint task force and the war against Boko Haram insurgency in Nigeria, 2009 to 2018. MSc diss., University of Nigeria, Nsukka. 
Delia, D., Barkindo, N. A., \& Jacobson, D. (2015). Religiosity and rebellion in Nigeria: Considering Boko Haram in the radical tradition. Studies in Conflict \& Terrorism, 38(7), 510-528.

Ebiede, T. M., Langer, A. \& Tosun, J. (2020). Disarmament, demobilisation, and reintegration: Analysing the outcomes of Nigeria's post-amnesty programme. Stability: International Journal of Security \& Development, 9(1), 1-17.

Etekpe, A. (2013). 'Peace and development in Nigeria: The amnesty experience in the Niger Delta of Nigeria. International Journal of Law and Conflict Resolution, 1(1), 099-107.

Felbab-Brown, V. (2018). The limits of punishment, transitional justice and violent extremism. Tokyo: United Nations University - Centre for Policy Research. 1166. Available online https://i.unu.edu/media/cpr.unu.edu/post/2761/LoPWeb070119.pdf (Accessed 12 June 2020).

Gilligan, M. J., Mvukiyehe, E. N., \& Samii, C. (2013). Reintegrating rebels into civilian life: Quasiexperimental evidence from Burundi. Journal of Conflict Resolution, $57(4), 598-626$.

Godin, K., Stapleton, J., Kirkpatrick, S. I., Hanning, R.M., \& Leatherdale, S.T. (2015). Applying systematic review search methods to the grey literature: a case study examining guidelines for school-based breakfast programs in Canada. Systematic Reviews, 4(1), 138.

Grip, L. \& Kotajoki, J. (2019). 'Deradicalisation, disengagement, rehabilitation and reintegration of violent extremists in Conflict-affected contexts: A systematic literature review'. Conflict, Security \& Development, 19(4), 371-402.

Hassan, I. \& Tyvoll, J. (2018). After Boko Haram: Prospects for transitional justice in North East Nigeria. The Centre for Democracy and Development. Available at https://media.africaportal.org/documents/After_Boko_Haram_Prospects_for_Tr ansitional_Justice_in_the_North_East_pdf (Accessed 21 May 2019).

Heimer, C. (2001). 'Solving the problem of trust' in Cook. K. (ed). Trust in society. New York: Russell Sage, 40-88. 
Higgins, J., \& Green, S. (ed). Cochrane handbook for systematic reviews of interventions. 5.1.0 ed. Chichester, United Kingdom: The Cochrane Collaboration; 2011.

Home Office (2019). Operation of police powers under the Terrorism Act 2000 and subsequent legislation: Arrests, outcomes, and stop and search Great Britain, year ending $\quad$ September $2019 . \quad$ UK: Asset Publishing https://assets.publishing.service.gov.uk/government/uploads/system/uploads/atta chment_data/file/850457/police-powers-terrorism-sep2019-hosb3019.pdf (accessed 28 August 2020).

Ikoh, M.U. \& Ukpong, E. A. (2013). The Niger Delta crisis: Taming violence beyond the amnesty'. International Journal of Humanities and Social Science, 3(17), 146159.

Institute for Economics and Peace, (2019). Global Terrorism Index: Measuring the Impact of Terrorism, Institute for Economic and Peace, Sydney.

International Alert/UNICEF Nigeria, (2016). Bad blood: Perceptions of children born of conflict-related sexual violence and women and girls associated with Boko Haram in Northeast Nigeria. UNICEF.

Iwilade, A. (2017). Slipping through the net: Everyday agency of youth and the politics of Amnesty in Nigeria's Niger Delta (2009-2015)'. Journal of Contemporary African Studies, 35(3), 266-283.

Kaplan, O. \& Nussio, E. (2018). Community counts: The social reintegration of excombatants in Colombia. Conflict Management and Peace Science, 35(2), 132153.

Kingma, K. (1997). 'Demobilisation of combatants after civil wars in Africa and their reintegration into civilian life. Policy Sciences, 30(3), 151-165.

Kmet, L. M., Lee, R. C., \& Cook, L. S. (2004). 'Standard quality assessment criteria for evaluating primary research papers. Alberta Heritage Foundation for Medical Research, 13(2), 1-22.

Koehler, D. (2016). Understanding deradicalization: Methods, tools and programs for countering violent extremism. London: Routledge. 
Koos, C., \& Pierskalla, J. (2016). The effects of oil production and ethnic representation on violent conflict in Nigeria: a mixed-methods approach. Terrorism and Political Violence, 28(5), 888-911.

Mahmood, O. S., \& Ani, N. C. (2018). Responses to Boko Haram in the Lake Chad Region: Policies, cooperation and livelihoods. Institute for Security Studies (ISS) Research Report.

Marsden, S. V. (2015). Conceptualising 'success' with those convicted of terrorism offences: Aims, methods, and barriers to reintegration'. Behavioral Sciences of Terrorism and Political Aggression, 7(2), 143-165.

McEvoy, K. (1998). Prisoner release and conflict resolution: International lessons for Northern Ireland. International Criminal Justice Review, 8(1), 33-60.

McEvoy, K., \& Shirlow, P. (2009). Re-imagining DDR: Ex-combatants, leadership and moral agency in conflict transformation. Theoretical Criminology, 13(1), 31-59.

Nwanze, E., Obingene, A. \& Njeze, I. (2018). Oil politics and implementation of amnesty programme in the Niger Delta, Nigeria, 2009-2017. IMTIJOTAS, 3(2), 69-87.

Okolie-Osemene, J. (2018). Nigeria: Perceptions of disarmament, demobilisation and reintegration modelling. Challenges and prospects for peace in Niger Delta'. Conflict Studies Quarterly, (24), 26-43.

Okurebia, S. \& Daniel. E. (2013). Management of amnesty programme for sustainable livelihood in the Niger-Delta region of Nigeria: Challenges and policy action. IOSR Journal of Business and Management (IOSR-JBM), 14(3), 26-42.

Olusola, O. (2013). The consequences of militancy in Nigeria's Niger Delta. JORINDJournal of Research in National Development, 11(2), 149-157.

Onyima, J. K. (2017). Sub-Saharan Africa: Societal reintegration of ex-militant youths. Conflict Studies Quarterly, 21, 76-100.

Pagano, S., \& Aviles, W. (2020). Reintegrating the radicalised: Challenges, lessons learned, and how to overcome barriers. NSI Reachback Report.

Phayal A., Khadka P. B., \& Thyne, C. L. (2015). What makes an ex-combatant happy? A micro-analysis of disarmament, demobilization, and reintegration in South Sudan. International Studies Quarterly, Online first 
Raimi, L., Bieh, N. N., \& Zorbari, K. (2017). In search of lasting calmness: How sustainable is the federal government's amnesty program as a peace strategy in the Niger Delta region of Nigeria?'. International Journal of African Development, 4(2), 7.

Riley, J., Pearson, K., Schneider, M. K., \& Stimeling, L. (2017) 'Escaping the LRA: Examining the decision to disengage from militarized dissident groups. African Security, 10(2), 80-102.

Schuurman, B. (2018). 'Research on terrorism, 2007-2016: A review of data, methods, and authorship.' Terrorism and Political Violence, 1-16

Tobor, J. (2016). Culture and the amnesty program in the Niger Delta region of Nigeria. European Journal of Research in Social Sciences, 4(3), 14-22.

Touitou, T. C. (2016). 'Does amnesty programme in Niger Delta have economic benefit to Nigeria?'. Asian Business Research Journal, 1, 1-7.

Umoh, O. O., Thompson, E., \& Adick A. 'Ex-militants' substance use and their perceptions of the effectiveness of amnesty programme in the Niger Delta. Journal of Mental Health Care, 1(1), 1-19. 
Table 1. Showing study characteristics

Figure 1. Showing a flow chart of the systematic literature review process 


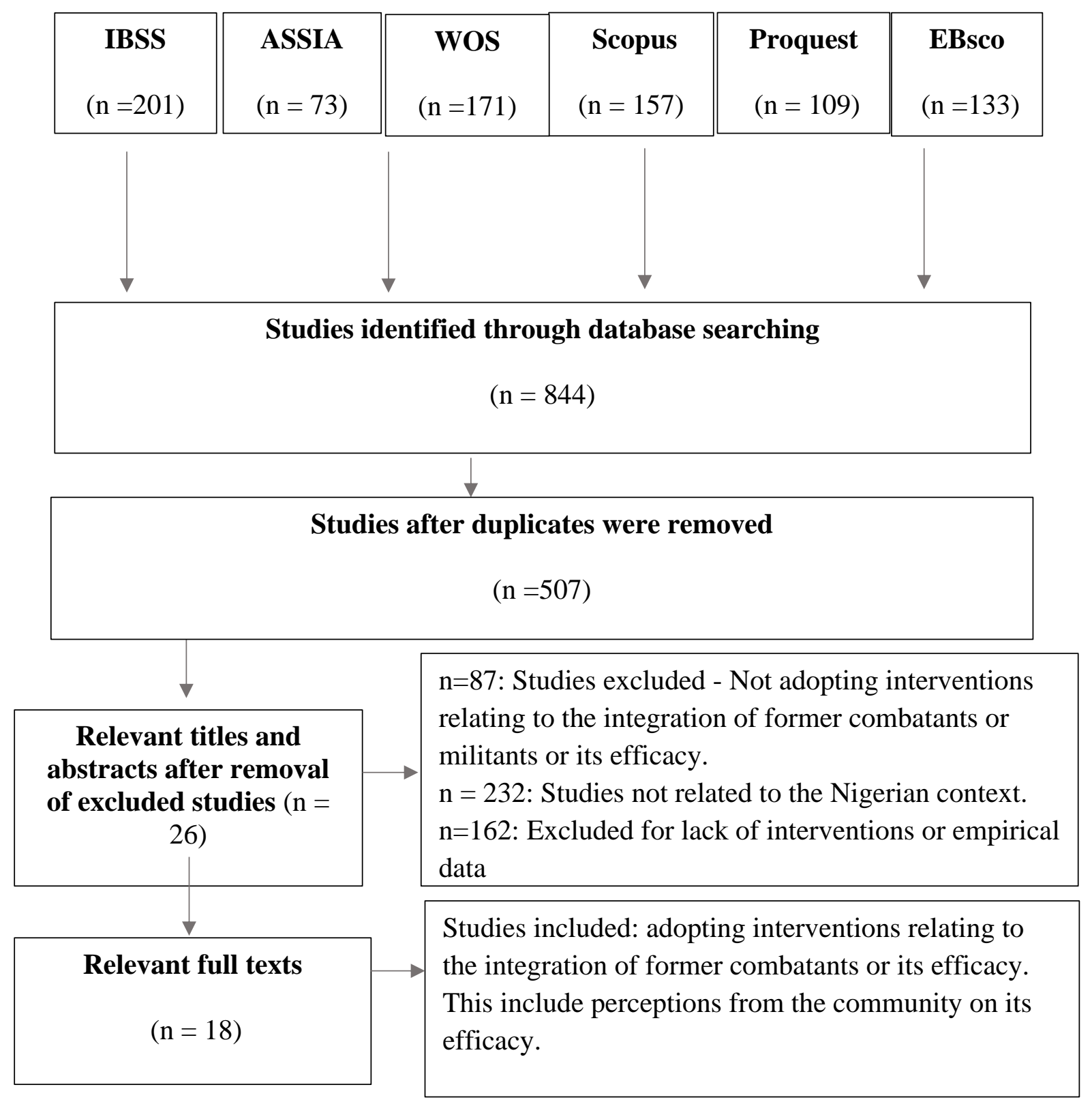

Figure 1. Showing a flow chart of the systematic literature review process 
[Insert Table 1 Here] Appendix: Table showing study characteristics

Table 1. Showing study characteristics

\begin{tabular}{|c|c|c|c|c|c|}
\hline Study & Aims & Methods & Sample population & Main findings & Conclusion \\
\hline $\begin{array}{l}\text { Onyima, } \\
2017\end{array}$ & $\begin{array}{l}\text { The study explored the } \\
\text { meaning of reintegration } \\
\text { to different segments of } \\
\text { the society and how the } \\
\text { amnesty programs fits } \\
\text { these descriptions. It also } \\
\text { draws on the extent to } \\
\text { which the ex-militants } \\
\text { are reintegrated into } \\
\text { civilian life } \\
\text { economically, politically } \\
\text { and socially. }\end{array}$ & $\begin{array}{l}\text { Questionnaire, interviews and } \\
\text { focus group discussions }\end{array}$ & $\begin{array}{l}\text { sixty ex-militants and } \\
\text { eighteen community } \\
\text { leaders from Ijaw, Urhobo } \\
\text { and Itshekiri ethnic groups } \\
\text { in Nigeria. }\end{array}$ & $\begin{array}{l}\text { Discrepancies between the way the } \\
\text { reintegration package was carried out } \\
\text { fell short of what the ex-militants and } \\
\text { the communities perceive } \\
\text { reintegration to be. This had an } \\
\text { implication on the non-effective } \\
\text { reintegration of the ex-militants into } \\
\text { civilian life. } \\
\text { The factors such as failure to address } \\
\text { the cause and effects of the conflict, } \\
\text { alienation of the communities in the } \\
\text { amnesty program and inability to find } \\
\text { substitutes for the ex-militants } \\
\text { hindered effective reintegration. }\end{array}$ & $\begin{array}{l}\text { Reintegration exercise } \\
\text { needs to be based on the } \\
\text { context that produced } \\
\text { the conflict } \\
\text { The host communities } \\
\text { should be directly } \\
\text { involved in its design } \\
\text { and implementation. }\end{array}$ \\
\hline $\begin{array}{l}\text { Adebayo } \\
\text { and } \\
\text { Matsilele } \\
\text { (2019) }\end{array}$ & $\begin{array}{l}\text { The study examined } \\
\text { demobilisation, } \\
\text { rehabilitation, and } \\
\text { reintegration as } \\
\text { exemplified by the } \\
\text { amnesty programme and }\end{array}$ & $\begin{array}{l}\text { The study adopted participant } \\
\text { observation, in-depth } \\
\text { interviews and focus group } \\
\text { discussions in selected } \\
\text { communities in Yenagoa LGA } \\
\text { of Bayelsa State. }\end{array}$ & $\begin{array}{l}\text { The population comprised } \\
\text { of a purposively selected } \\
170 \text { members of the } \\
\text { communities in Yenagoa } \\
\text { LGA, including ex- } \\
\text { militants, religious leaders, }\end{array}$ & $\begin{array}{l}\text { Conflict resolution and reintegration } \\
\text { programmes failed to take into } \\
\text { cognisance inputs from members of } \\
\text { the community on how to } \\
\text { permanently resolve the crises. }\end{array}$ & $\begin{array}{l}\text { Community members } \\
\text { expressed } \\
\text { dissatisfaction and } \\
\text { concerns of not been } \\
\text { carried along in the } \\
\text { design and }\end{array}$ \\
\hline
\end{tabular}




\begin{tabular}{|c|c|c|c|c|c|}
\hline & $\begin{array}{l}\text { operation safe corridor, } \\
\text { with the aim of } \\
\text { highlighting possible } \\
\text { success areas, and areas } \\
\text { of shortcomings }\end{array}$ & & $\begin{array}{l}\text { and leaders of market } \\
\text { organisations, as well as } \\
\text { youth and traditional } \\
\text { leaders. }\end{array}$ & $\begin{array}{l}\text { Community ability to forgive but } \\
\text { resent being forced to forget harms } \\
\text { done }\end{array}$ & $\begin{array}{l}\text { implementation of } \\
\text { peace interventions. }\end{array}$ \\
\hline $\begin{array}{l}\text { Umoh, } \\
\text { Thompson, } \\
\text { and Adick }\end{array}$ & $\begin{array}{l}\text { The study focused on } \\
\text { perceptual differences } \\
\text { between substance } \\
\text { (alcohol and marijuana) } \\
\text { using ex-militants and } \\
\text { their non-using } \\
\text { counterparts on the } \\
\text { effectiveness of the } \\
\text { ongoing amnesty } \\
\text { programme in curbing } \\
\text { militancy in the Niger } \\
\text { Delta. }\end{array}$ & $\begin{array}{l}\text { Quantitative study involving } \\
\text { the use of questionnaire. }\end{array}$ & $\begin{array}{l}\text { About } 503 \text { respondents } \\
\text { were randomly drawn } \\
\text { from a population of ex- } \\
\text { militants }\end{array}$ & $\begin{array}{l}\text { More substance users militants than } \\
\text { non-users did not surrender ALL } \\
\text { weapons/ammunition at their disposal } \\
\text { to government agents at the } \\
\text { disarmament centres. }\end{array}$ & $\begin{array}{l}\text { Recommended that for } \\
\text { the relative peaceful } \\
\text { tempo in the Niger } \\
\text { Delta to be sustained } \\
\text { and/or improved upon, } \\
\text { ex-militants in the on- } \\
\text { going amnesty scheme } \\
\text { and indeed youth of this } \\
\text { region should be made } \\
\text { to benefit from focused } \\
\text { drug } \\
\text { prevention/treatment } \\
\text { interventions }\end{array}$ \\
\hline $\begin{array}{l}\text { Nwanze, } \\
\text { Obingene } \\
\text { and Njeze } \\
(2018)\end{array}$ & $\begin{array}{l}\text { The study explored } \\
\text { whether the } \\
\text { implementation of } \\
\text { disarmament programme } \\
\text { led to increase in oil } \\
\text { production in Nigeria. It } \\
\text { also ascertained whether }\end{array}$ & $\begin{array}{l}\text { The study design includes } \\
\text { interviews with the then } \\
\text { coordinator of Presidential } \\
\text { Amnesty programme, and ex- } \\
\text { militants from the Niger Delta } \\
\text { region. }\end{array}$ & $\begin{array}{l}\text { Interviews with the then } \\
\text { coordinator of Presidential } \\
\text { Amnesty programme, } \\
\text { (Rtd.) Gen Paul Bogoro } \\
\text { and ex-militants from the } \\
\text { Niger Delta region. }\end{array}$ & $\begin{array}{l}\text { The implementation of disarmament } \\
\text { programme led to the increase in oil } \\
\text { production and the amnesty } \\
\text { programme led to reduction in } \\
\text { pipeline vandalism. }\end{array}$ & $\begin{array}{l}\text { The study found that the } \\
\text { implementation of } \\
\text { disarmament } \\
\text { programme has led to } \\
\text { the increase in oil } \\
\text { production in Nigeria. It } \\
\text { also found that the }\end{array}$ \\
\hline
\end{tabular}




\begin{tabular}{|c|c|c|c|c|c|}
\hline & $\begin{array}{l}\text { the implementation of } \\
\text { demobilisation } \\
\text { programme enhanced the } \\
\text { Niger Delta security } \\
\text { situation. }\end{array}$ & & & & $\begin{array}{l}\text { amnesty programme led } \\
\text { to significant reduction } \\
\text { in pipeline vandalism. }\end{array}$ \\
\hline $\begin{array}{l}\text { Hassan } \\
\text { and } \\
\text { Tyvoll, } \\
2018\end{array}$ & $\begin{array}{l}\text { Four scoping studies in } \\
\text { north-eastern Nigeria to } \\
\text { address the atrocities } \\
\text { committed by Boko } \\
\text { Haram and the prevailing } \\
\text { attitudes of the } \\
\text { community toward } \\
\text { reconciliation }\end{array}$ & $\begin{array}{l}\text { 1,200 questionnaires were } \\
\text { randomly administered in four } \\
\text { Local Government Areas } \\
\text { (LGAs) in Adamawa, Borno } \\
\text { and Yobe states. } \\
\text { Questionnaires also } \\
\text { complemented with qualitative } \\
\text { findings of key informant } \\
\text { interviews and focus group } \\
\text { discussions. }\end{array}$ & $\begin{array}{l}1,200 \text { respondents } \\
\text { randomly administered } \\
\text { questionnaires }\end{array}$ & $\begin{array}{l}\text { Fear of Recidivist violence from the } \\
\text { repentant Boko Haram or Relapse } \\
\text { Request for economic restoration on } \\
\text { the community before reintegration }\end{array}$ & $\begin{array}{l}\text { Need to make provision } \\
\text { for community } \\
\text { members with avenues } \\
\text { of redress or dissent } \\
\text { Sort former Boko } \\
\text { Haram members into } \\
\text { classes based on } \\
\text { magnitude of alleged } \\
\text { crimes }\end{array}$ \\
\hline $\begin{array}{l}\text { Ikoh and } \\
\text { Ukpong, } \\
2013\end{array}$ & $\begin{array}{l}\text { The study investigated } \\
\text { the factors that are } \\
\text { responsible for the } \\
\text { renewed violence in the } \\
\text { Niger Delta region with a } \\
\text { view to finding solutions. } \\
\text { The study also explored } \\
\text { perception of amnesty by } \\
\text { deserters, as well as the }\end{array}$ & $\begin{array}{l}\text { A survey design involving the } \\
\text { administration of } \\
\text { questionnaire to } 293 \text { ex- } \\
\text { militants }\end{array}$ & 293 ex-militants & $\begin{array}{l}\text { The study finds that respondents were } \\
\text { of the opinion that the amnesty will } \\
\text { not result in the overall development } \\
\text { of the Niger Delta region. } \\
\text { Fear informed the decision by some } \\
\text { militants to withhold their arms and } \\
\text { ammunitions, as well as the outright } \\
\text { rejection of the amnesty. }\end{array}$ & $\begin{array}{l}\text { The results indicate a } \\
\text { high mean rate on fear } \\
\text { about the } \\
\text { comprehensive } \\
\text { implementation of the } \\
\text { amnesty programme } \\
\text { due to lack of trust and } \\
\text { confidence in the } \\
\text { politicians handling the }\end{array}$ \\
\hline
\end{tabular}




\begin{tabular}{|c|c|c|c|c|c|}
\hline & $\begin{array}{l}\text { pull and push factors to } \\
\text { militancy }\end{array}$ & & & & $\begin{array}{l}\text { programme, and the } \\
\text { failure of previous } \\
\text { government } \\
\text { empowerment } \\
\text { programmes. }\end{array}$ \\
\hline $\begin{array}{l}\text { Touitou } \\
\text { (2016) }\end{array}$ & $\begin{array}{l}\text { The study examined the } \\
\text { economic benefits of } \\
\text { Post amnesty Programme } \\
\text { to Nigeria. It also } \\
\text { determines the level of } \\
\text { effectiveness of the } \\
\text { implementation of the } \\
\text { Post Amnesty } \\
\text { Programme since its } \\
\text { inception in } 2009 \text {. }\end{array}$ & $\begin{array}{l}\text { Descriptive survey design } \\
\text { research method. }\end{array}$ & $\begin{array}{l}400 \text { Youths aged 15- } 39 \\
\text { years old who are the } \\
\text { major stakeholders and } \\
\text { recruited from Bayelsa } \\
\text { State, Rivers State and } \\
\text { Delta State }\end{array}$ & $\begin{array}{l}\text { The evidence suggest that Amnesty } \\
\text { programme is economically } \\
\text { beneficial to Nigeria. The programme } \\
\text { seems deemed to only enrich the } \\
\text { militants rather than to the entire } \\
\text { youths of the Niger Delta. It found } \\
\text { that amnesty programme seems to } \\
\text { lack sustainability. }\end{array}$ & $\begin{array}{l}\text { Though economically } \\
\text { beneficial the evidence } \\
\text { seems to suggest } \\
\text { political interest in the } \\
\text { Niger-Delta crisis, as } \\
\text { the Amnesty } \\
\text { programme meant for } \\
\text { the entire Niger Delta } \\
\text { youths seems now being } \\
\text { targeted at a handful of } \\
\text { persons with "god } \\
\text { fathers." }\end{array}$ \\
\hline $\begin{array}{l}\text { Okolie- } \\
\text { Osemene } \\
(2018)\end{array}$ & $\begin{array}{l}\text { The study investigated } \\
\text { the perceptions } \\
\text { communities have of the } \\
\text { DDR for ex-militants, as } \\
\text { well as the challenges } \\
\text { and prospects for peace } \\
\text { in the Niger Delta. }\end{array}$ & $\begin{array}{l}\text { primary and secondary data } \\
\text { comprising both qualitative } \\
\text { and quantitative study using } \\
\text { semi-structured interviews and } \\
\text { in-depth questionnaires. Polls } \\
\text { comprised of } 1887 \\
\text { respondents while qualitative }\end{array}$ & $\begin{array}{l}153 \text { respondents } \\
\text { interviewed in four states } \\
\text { including Akwa Ibom, } \\
\text { Bayelsa, Delta and Rivers } \\
\text { States. }\end{array}$ & $\begin{array}{l}\text { Strong support for Government } \\
\text { giving ex-militants that passed } \\
\text { through the non- } \\
\text { violence/rehabilitation training some } \\
\text { compensation package and } \\
\text { allowances in exchange for their } \\
\text { commitment not to return to conflict }\end{array}$ & $\begin{array}{l}\text { Non-payment of } \\
\text { compensations and } \\
\text { allowance hindered } \\
\text { successful reintegration } \\
\text { of former militants } \\
\text { alongside inadequate } \\
\text { funding and training } \\
\text { facilities }\end{array}$ \\
\hline
\end{tabular}




\begin{tabular}{|c|c|c|c|c|c|}
\hline & & $\begin{array}{l}\text { interviews were conducted } \\
\text { with } 153 \text { respondents }\end{array}$ & & $\begin{array}{l}\text { government's sincerity as far as } \\
\text { people-centred development is } \\
\text { concerned dominate perceptions of } \\
\text { reintegration programmes of former } \\
\text { combatant. }\end{array}$ & \\
\hline $\begin{array}{l}\text { Raimi, } \\
\text { Bieh and } \\
\text { Zorbari } \\
\text { (2017) }\end{array}$ & $\begin{array}{l}\text { The study examined the } \\
\text { sustainability of the } \\
\text { Amnesty Program in the } \\
\text { Niger Delta Region. The } \\
\text { study also evaluated the } \\
\text { programme's strategy to } \\
\text { deliver peace to the } \\
\text { region from the short and } \\
\text { long-term. Perspective. }\end{array}$ & $\begin{array}{l}\text { The study adopted a } \\
\text { descriptive method as well as } \\
\text { purposive and simple random } \\
\text { sampling technique }\end{array}$ & $\begin{array}{l}\text { A sample of } 320 \text { repentant } \\
\text { militants' respondents } \\
\text { recruited from Bayelsa and } \\
\text { Rivers. states. }\end{array}$ & $\begin{array}{l}\text { Amnesty as a strategy for peace is not } \\
\text { sustainable due to its inability to } \\
\text { address issues such as inadequate } \\
\text { infrastructure, adverse human } \\
\text { development, poverty and } \\
\text { environmental degradation among } \\
\text { others. }\end{array}$ & $\begin{array}{l}\text { The study concludes } \\
\text { that the amnesty } \\
\text { programme failed to } \\
\text { address the problems } \\
\text { that triggered } \\
\text { widespread discontent } \\
\text { and aggression in the } \\
\text { Niger Delta region have } \\
\text { still. }\end{array}$ \\
\hline $\begin{array}{l}\text { Iwilade, } \\
2017\end{array}$ & $\begin{array}{l}\text { The study explored } \\
\text { youth's manipulation of } \\
\text { Nigeria's } 2009 \text { amnesty } \\
\text { programme. }\end{array}$ & $\begin{array}{l}\text { Qualitative design } \\
\text { incorporating interviews. }\end{array}$ & $\begin{array}{l}\text { Interview data from } \\
\text { participant including } \\
\text { young men enrolled in } \\
\text { Nigeria Amnesty } \\
\text { programme. }\end{array}$ & $\begin{array}{l}\text { The study found a counter hegemonic } \\
\text { process through which the } \\
\text { manipulation of the amnesty } \\
\text { programme by youths are undertaken. } \\
\text { It also found that amnesty seems not } \\
\text { to provide a long-term solution. }\end{array}$ & $\begin{array}{l}\text { The study suggests the } \\
\text { need to consider culture, } \\
\text { ethnicity and } \\
\text { institutional shortfalls in } \\
\text { the way governance is } \\
\text { construed to avoid the } \\
\text { emergence of militancy. }\end{array}$ \\
\hline $\begin{array}{l}\text { Etekpe, } \\
2013\end{array}$ & $\begin{array}{l}\text { The study analysed the } \\
\text { impact of Amnesty } \\
\text { programme on } \\
\text { sustainable development }\end{array}$ & $\begin{array}{l}\text { Secondary method of data } \\
\text { collection and personal } \\
\text { interview }\end{array}$ & $\begin{array}{l}\text { Secondary method of data } \\
\text { collection and personal } \\
\text { interview }\end{array}$ & $\begin{array}{l}\text { The amnesty programme was } \\
\text { beneficial to the government, and the } \\
\text { oil companies, but not the host }\end{array}$ & $\begin{array}{l}\text { The amnesty } \\
\text { programme was } \\
\text { beneficial to the } \\
\text { government, and the oil }\end{array}$ \\
\hline
\end{tabular}




\begin{tabular}{|c|c|c|c|c|c|}
\hline & $\begin{array}{l}\text { and peace in the Niger } \\
\text { Delta region. }\end{array}$ & & & $\begin{array}{l}\text { communities and the repentant } \\
\text { militants }\end{array}$ & $\begin{array}{l}\text { companies, but not the } \\
\text { host communities and } \\
\text { the repentant militants }\end{array}$ \\
\hline $\begin{array}{l}\text { Felbab- } \\
\text { Brown et. } \\
\text { al. (2018). }\end{array}$ & $\begin{array}{l}\text { This case study provided } \\
\text { an overview of the } \\
\text { conflict with Boko } \\
\text { Haram and societal } \\
\text { perceptions toward } \\
\text { individuals accused of } \\
\text { association with Boko } \\
\text { Haram. }\end{array}$ & $\begin{array}{l}\text { "interviewed } 69 \text { interlocutors, } \\
\text { including Nigerian } \\
\text { government officials, military, } \\
\text { intelligence, police officers; } \\
\text { members and commanders of } \\
\text { CJTF; members of various } \\
\text { committees formed to } \\
\text { negotiate with Boko Haram; } \\
\text { international support partners, } \\
\text { such as for Operation Safe } \\
\text { Corridor and the rehabilitation } \\
\text { facility for low-risk women } \\
\text { and children and for } \\
\text { reconstruction; women and } \\
\text { children who have exited from } \\
\text { the rehabilitation facility; men, } \\
\text { women, and children who } \\
\text { spent time in detention for } \\
\text { alleged association with Boko } \\
\text { Haram and were released and } \\
\text { relatives of others who were } \\
\text { detained by the Nigerian }\end{array}$ & Same as previous column & $\begin{array}{l}\text { Community members expressed } \\
\text { rejection of either Boko Haram } \\
\text { members or those who lived under } \\
\text { the group' s rule } \\
\text { Distrust of Nigeria Reintegration } \\
\text { programme } \\
\text { Community members expressed } \\
\text { resentment towards the rehabilitation, } \\
\text { reintegration, and deradicalization } \\
\text { programme due to unequal access to } \\
\text { benefits. }\end{array}$ & $\begin{array}{l}\text { Rejection of the } \\
\text { reintegration of Boko } \\
\text { Haram and persons who } \\
\text { live under their rule. } \\
\text { Distrust of Nigeria } \\
\text { Reintegration } \\
\text { programme. } \\
\text { Community members } \\
\text { expressed resentment } \\
\text { towards the } \\
\text { rehabilitation, } \\
\text { reintegration, and } \\
\text { deradicalization } \\
\text { programme due to } \\
\text { unequal access to } \\
\text { benefits }\end{array}$ \\
\hline
\end{tabular}




\begin{tabular}{|c|c|c|c|c|c|}
\hline & & $\begin{array}{l}\text { government or CJTF; } \\
\text { representatives of Nigerian } \\
\text { NGOs and international NGOs } \\
\text { operating in Nigeria; Nigerian } \\
\text { lawyers and human rights } \\
\text { advocates; victims' groups' } \\
\text { representatives; } \\
\text { representatives of Nigeria's } \\
\text { business community; and } \\
\text { Nigerian journalists, } \\
\text { academics, and researchers } \\
\text { (Felbab Browne et al.,2018, } \\
\text { p.88-89). }\end{array}$ & & & \\
\hline $\begin{array}{l}\text { Mahmood } \\
\text { and Ani } \\
\text { (2018) }\end{array}$ & $\begin{array}{l}\text { The report address } \\
\text { profiles, current } \\
\text { responses and challenges } \\
\text { associated with Boko } \\
\text { Haram. }\end{array}$ & $\begin{array}{l}\text { Mixed method design } \\
\text { involving both primary and } \\
\text { secondary data was employed. }\end{array}$ & $\begin{array}{l}75 \text { total interviews were } \\
\text { conducted in the lake chad } \\
\text { region including Nigeria. } \\
\text { Participants include } \\
\text { government officials, civil } \\
\text { society members, } \\
\text { diplomatic representatives, } \\
\text { humanitarian organisation } \\
\text { personnel, vigilante } \\
\text { members, , security } \\
\text { representatives and } \\
\text { traditional leaders. }\end{array}$ & $\begin{array}{l}\text { Resistance by the community towards } \\
\text { the reintegration of former Boko } \\
\text { Haram members due to preferential } \\
\text { treat accorded the latter. }\end{array}$ & $\begin{array}{l}\text { Perceived preferential } \\
\text { treatment of former } \\
\text { combatants limits their } \\
\text { reintegration into the } \\
\text { society. }\end{array}$ \\
\hline
\end{tabular}




\begin{tabular}{|c|c|c|c|c|c|}
\hline $\begin{array}{l}\text { Tobor, } \\
(2016)\end{array}$ & $\begin{array}{l}\text { The study examined } \\
\text { cultural values, } \\
\text { traditions, and beliefs } \\
\text { and explore whether they } \\
\text { might contribute to the } \\
\text { successful } \\
\text { implementation of the } \\
\text { Niger Delta amnesty } \\
\text { program }\end{array}$ & $\begin{array}{l}\text { Field notes of observations, } \\
\text { in-depth interviews, and } \\
\text { review of documents on the } \\
\text { amnesty program. }\end{array}$ & $\begin{array}{l}\text { Field notes compositions, } \\
\text { observations, journal } \\
\text { entries, discussions, and } 20 \\
\text { face-to-face interviews } \\
\text { with ex-militants from the } \\
\text { Urhobo. }\end{array}$ & $\begin{array}{l}\text { The implementer of the amnesty } \\
\text { programme failed to take into } \\
\text { account the significant role of the } \\
\text { cultures of the Niger Delta } \\
\text { communities }\end{array}$ & $\begin{array}{l}\text { Neglect of the function } \\
\text { of the cultures of the } \\
\text { Niger Delta } \\
\text { communities in } \\
\text { enhancing the amnesty } \\
\text { programme. }\end{array}$ \\
\hline $\begin{array}{l}\text { Okurebia } \\
\text { and Daniel } \\
(2013) \text {. }\end{array}$ & $\begin{array}{l}\text { The study assessed the } \\
\text { success of the amnesty } \\
\text { programme to deliver a } \\
\text { sustainable livelihood for } \\
\text { the repentant ex- } \\
\text { militants. It also assessed } \\
\text { its ability to restore } \\
\text { peace and security in the } \\
\text { region }\end{array}$ & $\begin{array}{l}\text { Questionnaire and interview } \\
\text { methods randomly } \\
\text { administered in three of the } \\
\text { nine states of the region }\end{array}$ & $\begin{array}{l}\text { Eighty five (85) ex- } \\
\text { militants, twelve (12) } \\
\text { officials, and one hundred } \\
\text { and sixteen (116) other } \\
\text { persons. }\end{array}$ & $\begin{array}{l}\text { The success of the amnesty } \\
\text { programmes is questionable as more } \\
\text { post amnesty crimes emerged in the } \\
\text { region. } \\
\text { Increased rate of drug consumption } \\
\text { among the militants } \\
\text { ex-militant rehabilitation camps lack } \\
\text { expert personnel and basic } \\
\text { rehabilitation facility }\end{array}$ & $\begin{array}{l}\text { The success of the } \\
\text { amnesty programmes is } \\
\text { questionable as more } \\
\text { post amnesty crimes } \\
\text { emerged in the region. } \\
\text { Increased rate of drug } \\
\text { consumption among the } \\
\text { militants } \\
\text { Ex-militant } \\
\text { rehabilitation camps } \\
\text { lack expert personnel } \\
\text { and basic rehabilitation } \\
\text { facility }\end{array}$ \\
\hline $\begin{array}{l}\text { Centre for } \\
\text { Democrac }\end{array}$ & $\begin{array}{l}\text { The study explored } \\
\text { respondents' disposition }\end{array}$ & $\begin{array}{l}\text { Scoping study conducted in } \\
\text { Borno and Yobe state using }\end{array}$ & $\begin{array}{l}\text { Interviews and focus group } \\
\text { conducted with }\end{array}$ & $\begin{array}{l}\text { Community's survivor resentment of } \\
\text { the attention directed at resettling }\end{array}$ & $\begin{array}{l}\text { Distrust pervaded } \\
\text { communities at different }\end{array}$ \\
\hline
\end{tabular}




\begin{tabular}{|c|c|c|c|c|c|}
\hline $\begin{array}{l}\text { y and } \\
\text { Developm } \\
\text { ent (2017) }\end{array}$ & $\begin{array}{l}\text { towards reintegration and } \\
\text { resettlement of repentant } \\
\text { former Boko Haram } \\
\text { combatants. }\end{array}$ & $\begin{array}{l}\text { interviews and focus groups } \\
\text { discussion as techniques for } \\
\text { data collection. }\end{array}$ & $\begin{array}{l}\text { purposively selected ex- } \\
\text { boko haram combatants, } \\
\text { survivors of the group's } \\
\text { insurgency, the civilian } \\
\text { joint task force, members } \\
\text { of the Nigerian military, } \\
\text { hunters, camp officials, } \\
\text { religious leaders, security } \\
\text { agents, students, } \\
\text { academics, primary school } \\
\text { teachers and development } \\
\text { workers. }\end{array}$ & $\begin{array}{l}\text { former Boko Haram by programmes } \\
\text { such Operation Safe Corridors. } \\
\text { Distrust of security agencies handling } \\
\text { resentment due to alleged human } \\
\text { right abuse. } \\
\text { Perceived imbalance on the level of } \\
\text { preferential treatment accorded Boko } \\
\text { Haram and the community with the } \\
\text { former deemed to be more } \\
\text { empowered and prepared for } \\
\text { resettlement than the communities } \\
\text { suffering from the harms resulting } \\
\text { from the acts of these former } \\
\text { combatants of Boko Haram. }\end{array}$ & $\begin{array}{l}\text { level including distrust } \\
\text { of security agents and } \\
\text { distrust among the } \\
\text { Christian and Muslim } \\
\text { community. } \\
\text { Stigmatisation of the } \\
\text { wives and children of } \\
\text { former boko haram } \\
\text { combatants }\end{array}$ \\
\hline $\begin{array}{l}\text { Ebiede, } \\
\text { Langer and } \\
\text { Tosun } \\
(2020)\end{array}$ & $\begin{array}{l}\text { The study examined the } \\
\text { effect of the Post- } \\
\text { Amnesty Programme } \\
\text { (PAP) introduced in } \\
\text { Nigeria in } 2009 \text { in } \\
\text { fostering reintegration } \\
\text { and its general efficacy }\end{array}$ & Qualitative interviews & $\begin{array}{l}75 \text { semi-structured } \\
\text { interviews with } \\
\text { stakeholders, including ex- } \\
\text { militants and civilians } \\
\text { from communities in } \\
\text { Bayelsa, } \\
\text { government officials } \\
\text { responsible for the } \\
\text { implementation of } \\
\text { Nigeria's PAP, leaders of } \\
\text { local civil society }\end{array}$ & $\begin{array}{l}\text { The programme contributed to the } \\
\text { reduction of small arms and light } \\
\text { weapons (SALW). } \\
\text { Prestige and financial reward } \\
\text { individuals are receiving from being } \\
\text { enrolled in the PAP limits the } \\
\text { efficacy of the programme. } \\
\text { Community members fear of crime } \\
\text { commission by former militants }\end{array}$ & $\begin{array}{l}\text { The programme has } \\
\text { been ineffective in } \\
\text { reintegrating ex- } \\
\text { militants into civilian } \\
\text { life because of serious } \\
\text { shortcomings in its } \\
\text { design. } \\
\text { Financial rewards paid } \\
\text { to repentant militants } \\
\text { limits its efficacy. }\end{array}$ \\
\hline
\end{tabular}




\begin{tabular}{|c|c|c|c|c|c|}
\hline & & & $\begin{array}{l}\text { organisations (CSOs), and } \\
\text { academics in the Niger } \\
\text { Delta region }\end{array}$ & & $\begin{array}{l}\text { Training of ex-militant } \\
\text { was not informed by a } \\
\text { labour market } \\
\text { assessment and hence } \\
\text { limiting its efficacy due } \\
\text { to high level of } \\
\text { joblessness. }\end{array}$ \\
\hline $\begin{array}{l}\text { Internation } \\
\text { al } \\
\text { Alert/UNI } \\
\text { CEF } \\
\text { Nigeria } \\
(2016)\end{array}$ & $\begin{array}{l}\text { The study aimed to } \\
\text { identify and understand } \\
\text { the perceptions of } \\
\text { communities, families, } \\
\text { religious and traditional } \\
\text { leaders, and government } \\
\text { stakeholders towards } \\
\text { affected girls, children } \\
\text { and women captured by } \\
\text { or rescued from Boko } \\
\text { Haram. It also identified } \\
\text { what drove these } \\
\text { perceptions and the } \\
\text { consequences for their } \\
\text { safety and reintegration }\end{array}$ & $\begin{array}{l}19 \text { focus group discussions } \\
\text { and interviews. }\end{array}$ & $\begin{array}{l}19 \text { focus group discussions } \\
\text { (FGDs) with impacted } \\
\text { family members, religious } \\
\text { leaders, traditional } \\
\text { rulers, } 12 \text { community } \\
\text { leaders, women leaders, } \\
\text { government } \\
\text { representatives and service } \\
\text { providers. The team also } \\
\text { collected } 14 \text { key informant } \\
\text { interviews (KIIs) with } \\
\text { survivors (women and } \\
\text { girls) with and without } \\
\text { children born of sexual } \\
\text { violence by JAS }\end{array}$ & $\begin{array}{l}\text { Communities feared children, girls } \\
\text { and women who are perceived to be } \\
\text { associated with Boko Haram and who } \\
\text { are arriving in IDP camps from areas } \\
\text { liberated in the northeast. }\end{array}$ & $\begin{array}{l}\text { Fear of likely harm } \\
\text { orchestrated by } \\
\text { children, girls and } \\
\text { women who are } \\
\text { perceived to be } \\
\text { associated with Boko } \\
\text { Haram and who are } \\
\text { arriving in IDP camps } \\
\text { from areas liberated in } \\
\text { the northeast. }\end{array}$ \\
\hline
\end{tabular}


